\title{
UPPER CAMPANIAN CALCAREOUS NANNOFOSSILS FROM A CORE OF WELL 2-RSS-1, PELOTAS BASIN, BRAZIL
}

\author{
RODRIGO DO MONTE GUERRA \\ Laboratório de Micropaleontologia, UNISINOS, Av. Unisinos, 950, 93022-000, São Leopoldo, RS, Brasil. \\ rmguerra@unisinos.br \\ LUCIO RIOGI TOKUTAKE \\ Departamento de Exploração, Setor de Sedimentologia e Estratigrafia, PETROBRAS, Unidade UN-ES, Av. Fernando Ferrari, \\ 1000, 29075-973, Vitória, ES, Brasil.tokutake@ petrobras.com.br \\ GERSONFAUTH \\ Laboratório de Micropaleontologia, UNISINOS, Av. Unisinos, 950, 93022-000, São Leopoldo, RS, Brasil. \\ gersonf@unisinos.br
}

\begin{abstract}
This study aimed to determine calcareous nannofossils associations and their standard biozones, taking into account a previous study for the Cretaceous of the Pelotas Basin conducted by Petróleo Brasileiro S.A. - PETROBRAS. Twenty-three slides from samples of a core from well 2-RSS-1 (depth interval of 4,480.35-4,487.70 m) were analyzed, drilled in the offshore portion of the basin. Thirty-two nannofossil species were recognized, with the most important being Arkhangelskiella cymbiformis, Broinsonia parca constricta, Calculites obscurus, Eiffellithus turriseiffelii, Microrhabdulus decoratus, Micula decussata, Reinhardtites levis, Retecapsa crenulata, Tranolithus orionatus, Uniplanarius sissinghii and Uniplanarius trifidus. The coexistence of the species B. parca constricta and $R$. levis in the slides indicates the interval between the international biozones $\mathrm{CC} 22 \mathrm{~b}$ and $\mathrm{CC} 23 \mathrm{a}$. According to the international zonation proposed for the Cretaceous, the interval studied seems to be deposited in the upper Campanian boundary.
\end{abstract}

Key words: calcareous nannofossils, Pelotas Basin, biostratigraphy, Cretaceous, Campanian.

\begin{abstract}
RESUMO - Este trabalho enfoca a caracterização dos nanofósseis calcários da bacia de Pleotas e sua inserção nas respectivas biozonas internacionais, como refinamento a estudos prévios feitos nos depósitos cretáceos da bacia. Foram analisadas 23 lâminas de amostras procedentes do intervalo de 4.480,35 até 4.487,70 m de testemunho do poço 2-RSS-1, perfurado na porção offshore da bacia. O estudo reconheceu 32 espécies, das quais se destacam Arkhangelskiella cymbiformis, Broinsonia parca constricta, Calculites obscurus, Eiffellithus turriseiffelii, Microrhabdulus decoratus, Micula decussata, Reinhardtites levis, Retecapsa crenulata, Tranolithus orionatus, Uniplanarius sissinghii e Uniplanarius trifidus. A coexistência das espécies $R$. levis e B. parca constricta indica o intervalo entre as biozonas internacionais CC22b e CC23a. De acordo com o zoneamento internacional proposto para o Cretáceo, pode-se inferir que o intervalo estudado foi depositado durante o Campaniano superior.
\end{abstract}

Palavras-chave: manofósseis calcários, bacia de Pelotas, bioestratigrafia, Cretáceo, Campaniano.

\section{INTRODUCTION}

The deep wells drilled in the Pelotas Basin by PETROBRAS between the 1970s and 1980s represent a rare opportunity to understand the geological evolution of the region during the Cretaceous and Cenozoic. Refined biostratigraphic studies have been carried out aimed at better understanding the microfossil occurrence and distribution, as follow: Closs (1970), Thiesen (1977), Madeira-Falcetta et al. (1980), Koutsoukos (1982), Anjos (2004), Anjos \& Carreño (2004) and Coimbra et al. (2009) regarding foraminifers; Sanguinetti (1980), Ornellas (1981), Carreño et al. (1997) and Ceolin \& Fauth (2009) regarding ostracods; Gomide (1989) regarding calcareous nannofossils; and Regali et al. (1974),
Arai et al. (2006) and Premaor et al. (2007) regarding palynomorphs. Based on calcareous nannofossils, Gomide (1989) presented the biochronostratigraphy of the marine section between the Cretaceous and Miocene.

Located between latitudes $28^{\circ} \mathrm{S}$ and $34^{\circ} \mathrm{S}$, the Pelotas Basin is bordered on the south by Polônio High, in Uruguay and on the north by the Florianópolis High (Bueno et al., 2007). It occupies an area of approximately $210,000 \mathrm{~km}^{2}$, of which 40,000 $\mathrm{km}^{2}$ are in the continental area (Dias et al., 1994; Figure 1).

According to Milani et al. (1994) and Fontana (1996), the proximal portion of the Pelotas Basin overlaid on the continental crust (Paraná Basin), and basalt extruded in the beginning of the pre-rift phase, while the distal portion overlaid on the ocean floor. 
Gonçalves et al. (1979) separated the northern portion of the Pelotas Basin, known as the Florianópolis Shelf, an intense volcanic zone featuring the earliest stages of the opening of

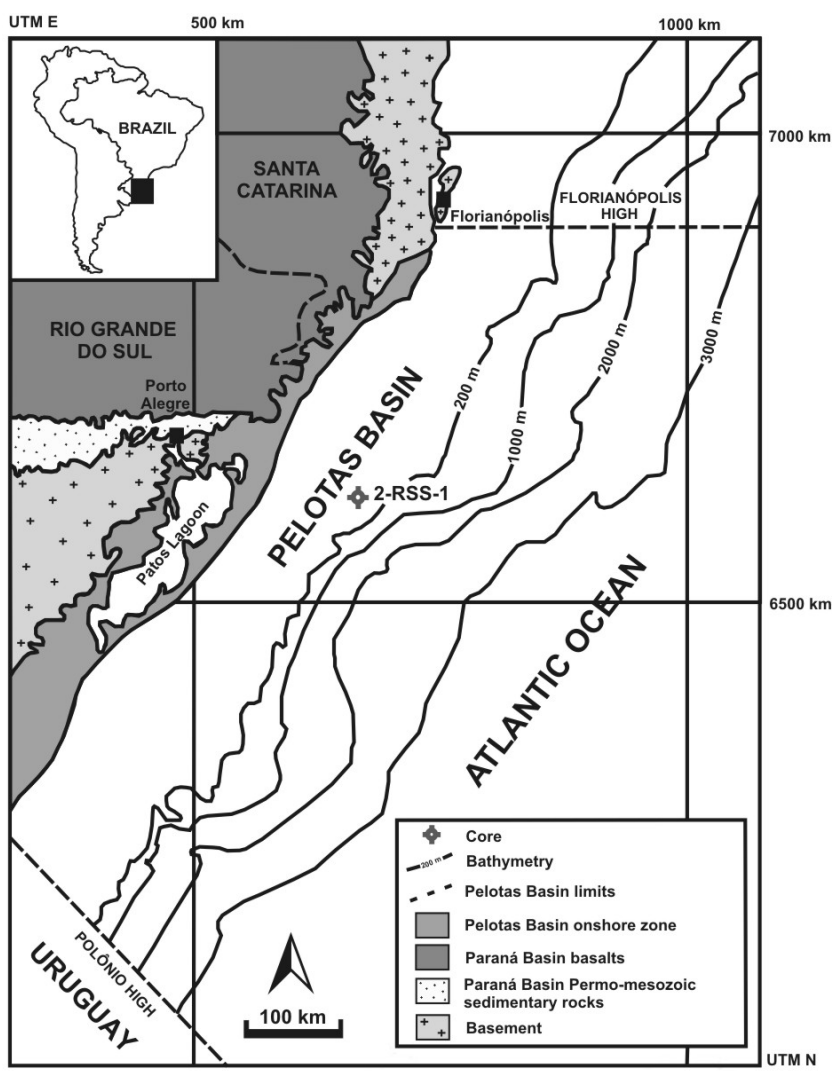

Figure 1. Simplified map of the Pelotas Basin showing its borders and well 2-RSS-1 (modified from Anjos \& Carreño, 2004). the South Atlantic Ocean, forming an igneous rock barrier named the Florianópolis High, which isolated the Pelotas Basin from the northern evaporitic basins. The Florianópolis High blocked the ocean circulation favoring a large restricted environment to the north represented by evaporitic layers (Azevedo, 2004). This lock remained with a low sedimentation rate until the Aptian. During the lower Albian, the Florianópolis Shelf sedimentary record becomes more substantial due to the open marine waters between the Santos and Pelotas basins (Gonçalves et al., 1979).

The interval studied in this work belongs to the Imbé Formation which consists of shales with rare intercalations of turbidite sandstones deposited in deep marine environments, aged from the Turonian to Recent (Dias et al., 1994).

\section{MATERIAL AND METHODS}

Twenty-three samples of a core from well 2-RSS-1, drilled in the offshore portion of the Pelotas Basin, were analyzed. They come from the depth interval 4,480.35-4,487.70 m, with a sampling interval ranging between 10 and $55 \mathrm{~cm}$ (Figure 2). Lithologically, the range (about $7.35 \mathrm{~m}$ ) is composed of darkgray micaceous siltstones.

The preparation of the slides was undertaken at the Laboratório de Micropaleontologia at the Universidade do Vale do Rio dos Sinos (UNISINOS), according to the method proposed by Antunes (1997). The species identified herein are reported in Appendix 1 and illustrated in Figures 3 and 4. The taxonomy follows Bown \& Young (1997). Perch-Nielsen (1985) and Burnett (1998) were widely consulted for help in the identification of species and biozones.

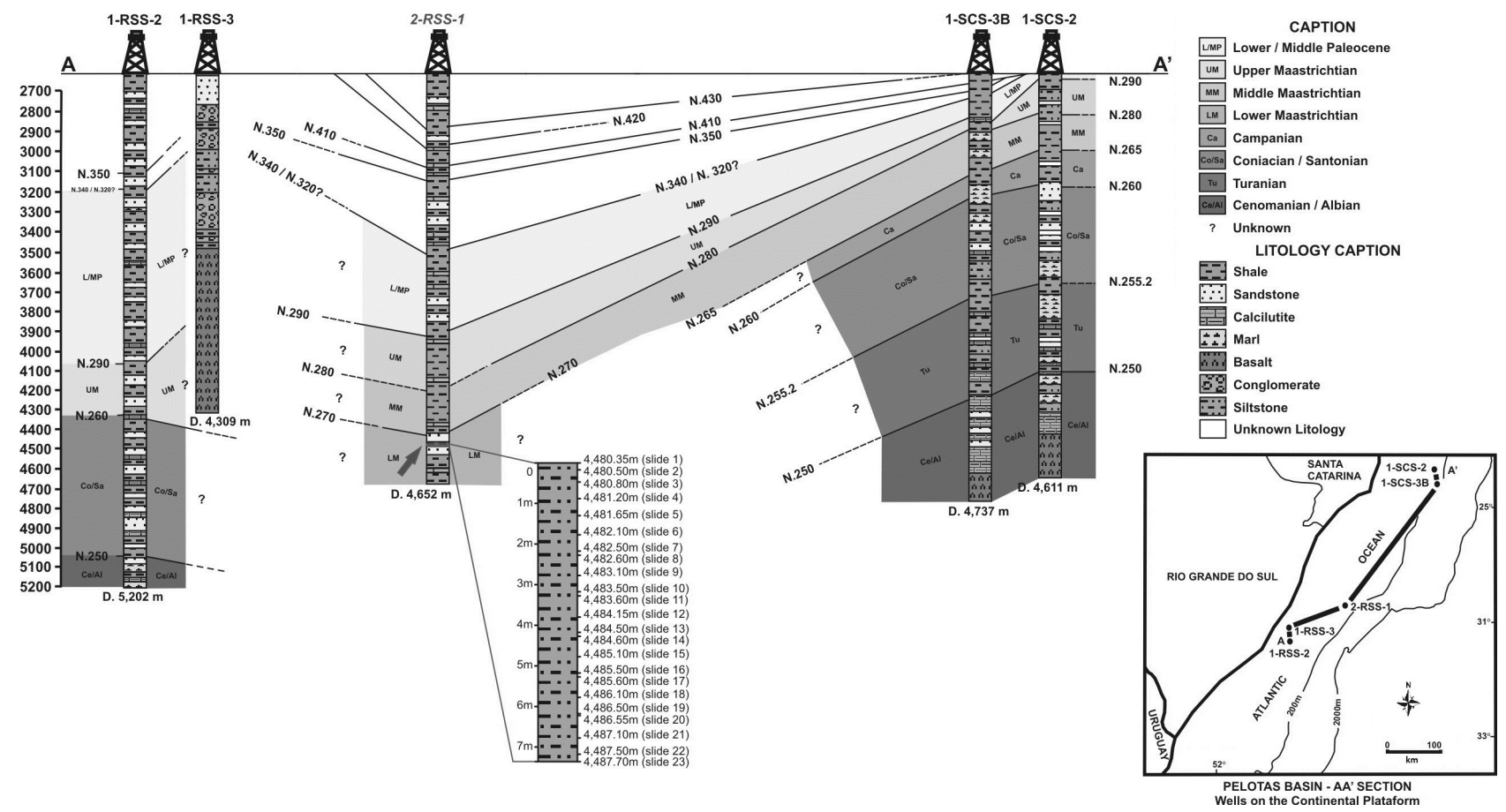

Figure 2. Detail of the interval studied in core 2-RSS-1, following the AA' section of Gomide (1989). The arrow indicates the interval studied. Dotted lines and question marks indicate areas where it was not possible to define the extent of the biozone (modified from Gomide, 1989). 

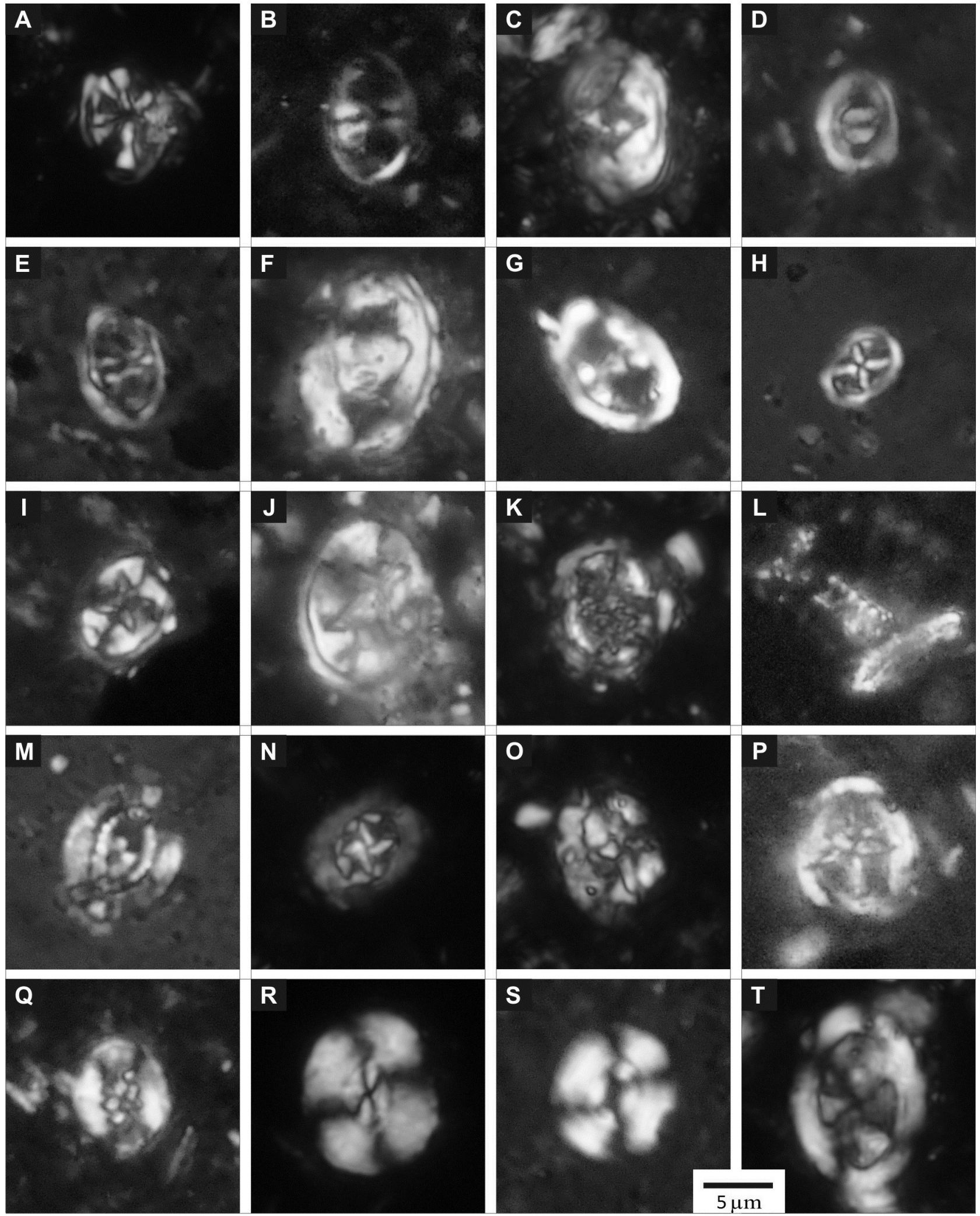

Figure 3. A, Ahmuellerella octoradiata, slide 2/4,480.50 m; B, Tranolithus orionatus, slide 11/4,483.60 m; C, Reinhardtites levis, slide 10/ 4,483.50 m; D, Zeugrhabdotus bicrescenticus, slide 1/4,480.35 m; E, Zeugrhabdotus diplogramus, slide 10/4,483.50 m; F, Zeugrhabdotus embergeri, slide 1/4,480.35 m; G, Zeugrhabdotus sigmoides, slide 22/4,487.50 m; H, Chiastozygus sp., slide 17/4,485.60 m; I, Eiffellithus gorkae, slide 1/4,480.35 m; J, Eiffellithus turriseiffelii, slide 7/4,482.50 m; K, Cribrosphaerella ehrenbergii, slide 10/4,483.50 m; L, Tetrapodorhabdus decorus, slide 5/4,481.65 m; M, Biscutum magnum, slide 17/4,485.60 m; N, Prediscosphaera cretacea, slide 20/ 4,486.55 m; O, Prediscosphaera spinosa, slide 13/4,484.50 m; P, Cretarhabdus conicus, slide 7/4,482.50 m; Q, Retecapsa crenulata, slide 16/4,485.50 m; R, Watznaueria barnesiae, slide 1/4,480.35 m; S, Watznaueria fossacincta, slide 1/4,480.35 m; T, Arkhangelskiella cymbiformis, slide 20/4,485.55 m. 


\section{BIOSTRATIGRAPHY}

The calcareous nannofossils are considered excellent biostratigraphic tools. These planktonic organisms had rapid speciation throughout their geological history, leaving modified descendants. The short time range, wide geographical distribution, and the facility to prepare the samples make calcareous nannofossils one of the most effective biostratigraphic tools since the Lower Jurassic. The stratigraphic distribution of calcareous nannofossils during the Cretaceous is fairly well known. Several authors have used different combinations of species distribution to establish biozones in different regions of the earth (PerchNielsen, 1985). The main cosmopolitan zonations, using Cretaceous calcareous nannofossils were established by Sissingh (1977), Roth (1978), Perch-Nielsen (1985), and Burnett (1998).

During the taxonomic study, the abundance of the species Arkhangelskiella cymbiformis (Figure 3T), Broinsonia parca constricta (Figure 4B), Calculites obscurus (Figure 4E), Eiffellithus turriseiffelii (Figure 3J), Microrhabdulus decoratus (Figure 4G), Micula decussata (Figure 4K),
Reinhardtites levis (Figure 3C), Retecapsa crenulata (Figure 3Q), Tranolithus orionatus (Figure 3B), Uniplanarius sissinghii (Figure 4I) and Uniplanarius trifidus (Figure 4J) was examined, and these species were considered Cretaceous biomarkers following Perch-Nielsen (1985). According to Sissingh (1977) and Perch-Nielsen (1985), the presence of $B$. parca constricta and $R$. levis together define the interval between the international biozones CC22b to CC23a. The CC22 zone, upper Campanian in age, is defined by the first occurrence of Quadrum trifidum (=Uniplanarius trifidus) until the last occurrence (LO) of Reinhardtites anthophorus. Sissingh (1977), however, suggested the division of the CC22 zone by the first occurrence of $R$. levis. The $\mathrm{CC} 23$ zone, upper Campanian/lower Maastrichtian in age, is defined by the LO of $R$. anthophorus until the LO of Tranolithus orionatus (=Tranolithus phacelosus). The LO of Broinsonia parca (=Aspidolhithus parcus) subdivides the CC23 zone (Sissingh, 1977).

Burnett (1998) suggested a new biozonation using Cretaceous calcareous nannofossils. According to the author, many bioevents used to define the Perch-Nielsen (1985) CC biozones are inappropriate for a global context (Figure 5).
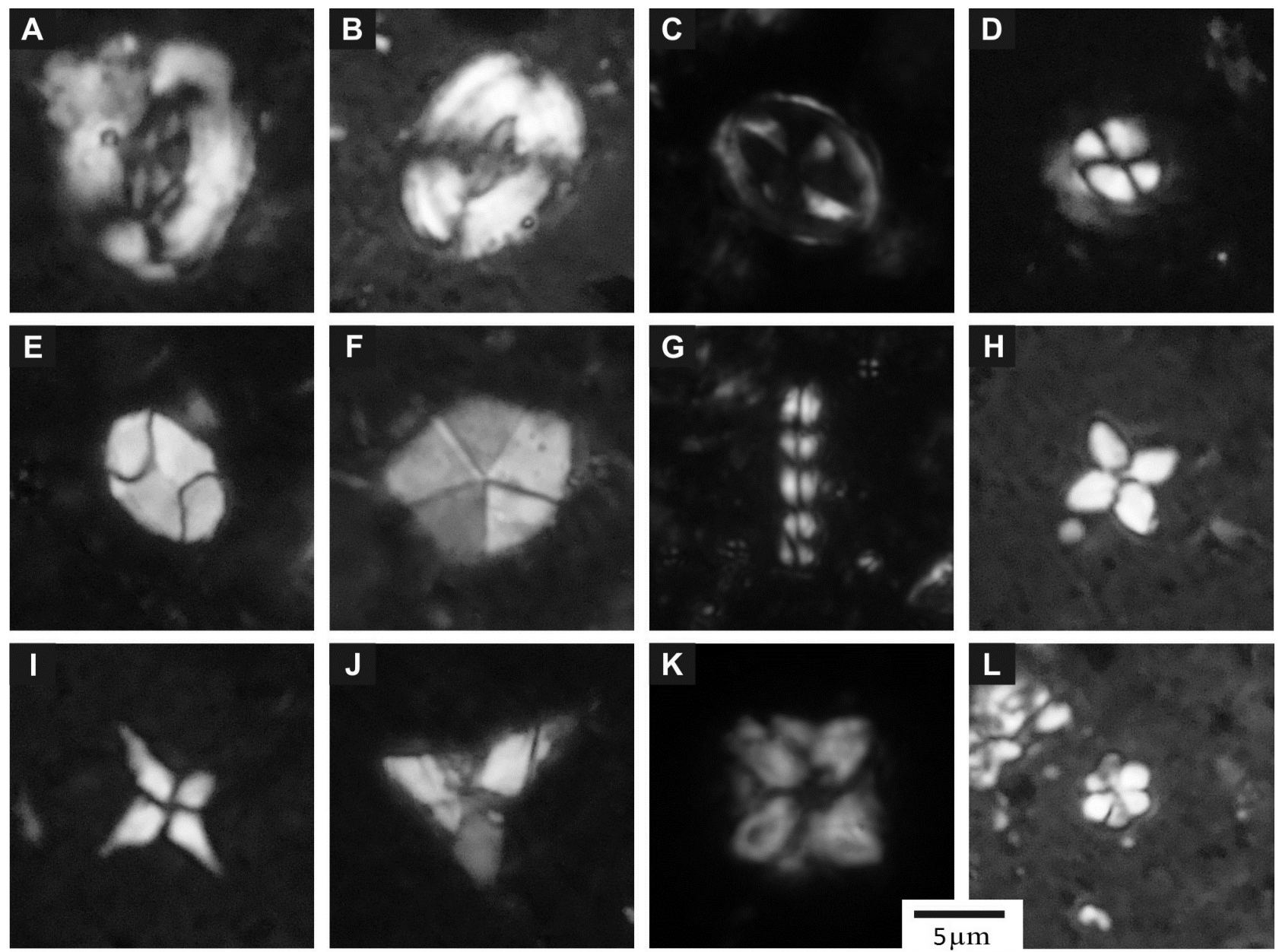

Figure 4. A, Broinsonia parca, slide 11/4,483.60 m; B, Broinsonia parca constricta, slide 18/4,486.10 m; C, Gartnerago segmentatum, slide 18/4,486.10 m; D, Markalius inversus, slide 22/4,487.50 m; E, Calculites obscurus, slide 2/4,480.50 m; F, Braarudosphaera bigelowii, slide 14/4,484.60 m; G, Microrhabdulus decoratus, slide 7/4,482.50 m; H, Uniplanarius gothicus, slide 22/4,487.50 m; I, Uniplanarius sissinghii, slide 5/4,481.65 m; J, Uniplanarius trifidus, slide 7/4,482.50 m; K, Micula decussata, slide 4/4,481.20 m; L, Hexalithus gardetiae, slide $18 / 4,486.10 \mathrm{~m}$. 


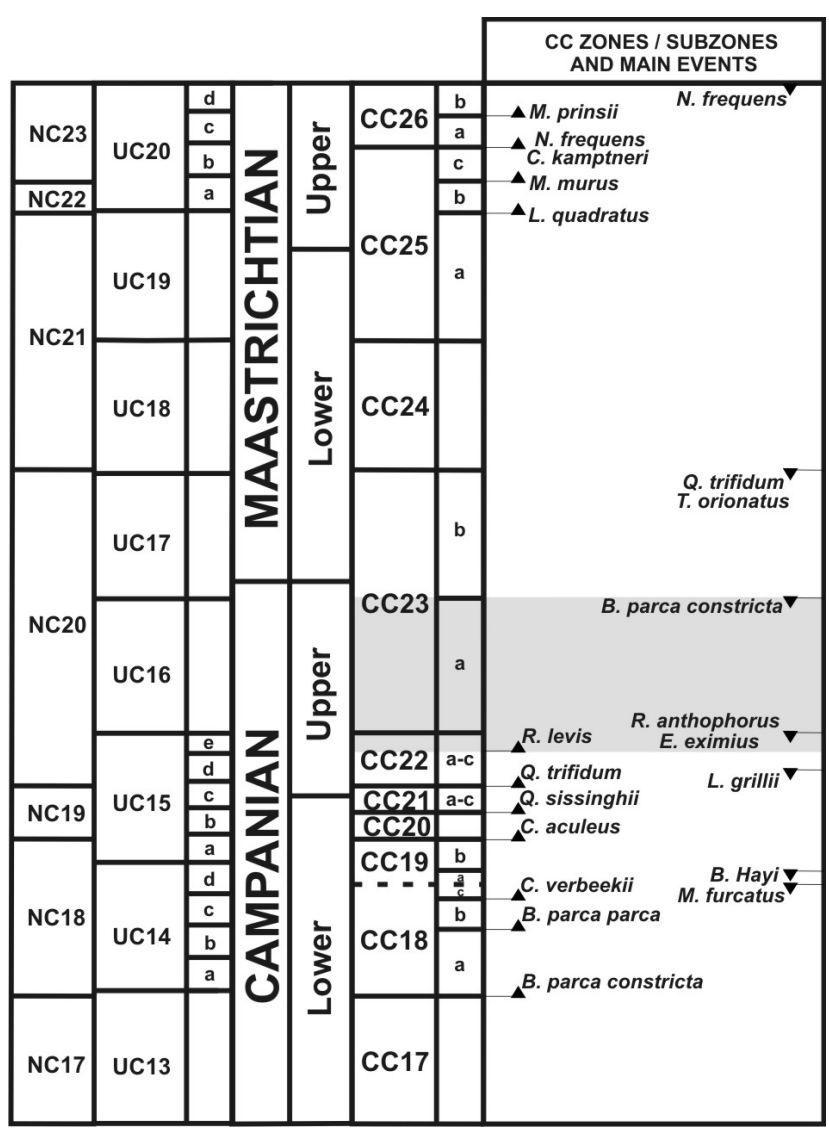

Figure 5. Correlation between the biozones of Roth (1978) (NC), Burnett (1998) (UC) and Perch-Nielsen (1985) (CC). The area in gray shows the interval studied herein (modified from Burnett, 1998).
The species $B$. parca constricta and $R$. levis studied in this paper were also of great importance in the biozone proposed by Burnett (1998). According to the author, in the Tethyanintermediate zone $\left(\right.$ Thethyan $=45^{\circ} \mathrm{N}-10^{\circ} \mathrm{S} /$ intermediate $=10$ $\left.35^{\circ} \mathrm{S}\right), R$. levis had its first occurrence in the UC14d zone, and B. parca constricta had its last occurrence in UC16. In the Boreal-intermediate zone $\left(\right.$ Boreal $=>50^{\circ} \mathrm{N} /$ intermediate $=50$ $\left.45^{\circ} \mathrm{N}\right)$, R. levis appeared in the UC15b zone, and $B$. parca constricta was extinguished in the UC16. For the Austral zone $\left(>35^{\circ} \mathrm{S}\right)$, it was not possible to detect the first occurrence of $R$. levis, but the extinction of B. parca constricta was also indicated in UC16. It is important to remark that the author did not use samples from the South Atlantic in general (Brazil), but rather only the extreme South Atlantic (Argentine shelf).

The species pointed out by Perch-Nielsen (1985) as Cretaceous (Micula decussata, Watznaueria barnesiae, and Eiffellithus gorkae) occur in almost all samples of the interval, have a homogeneous distribution along the profile, and are the most frequent in the material studied. Though Hexalithus gardetiae occurred only in one sample with a depth of 4,486.10 $\mathrm{m}$ (Figure 6).

Well 2-RSS-1 was studied previously by Gomide (1989) who proposed a framework using calcareous nannofossils, as previously mentioned. For the same depth analyzed in the present study, this author attributed a lower Maastrichtian age. Instead, based on data obtained in our study, associated with the Perch-Nielsen (1985) and Burnett (1998) biozones, we consider that the depth interval between 4,480.35-4,487.70 $\mathrm{m}$ was deposited in the upper Campanian boundary.

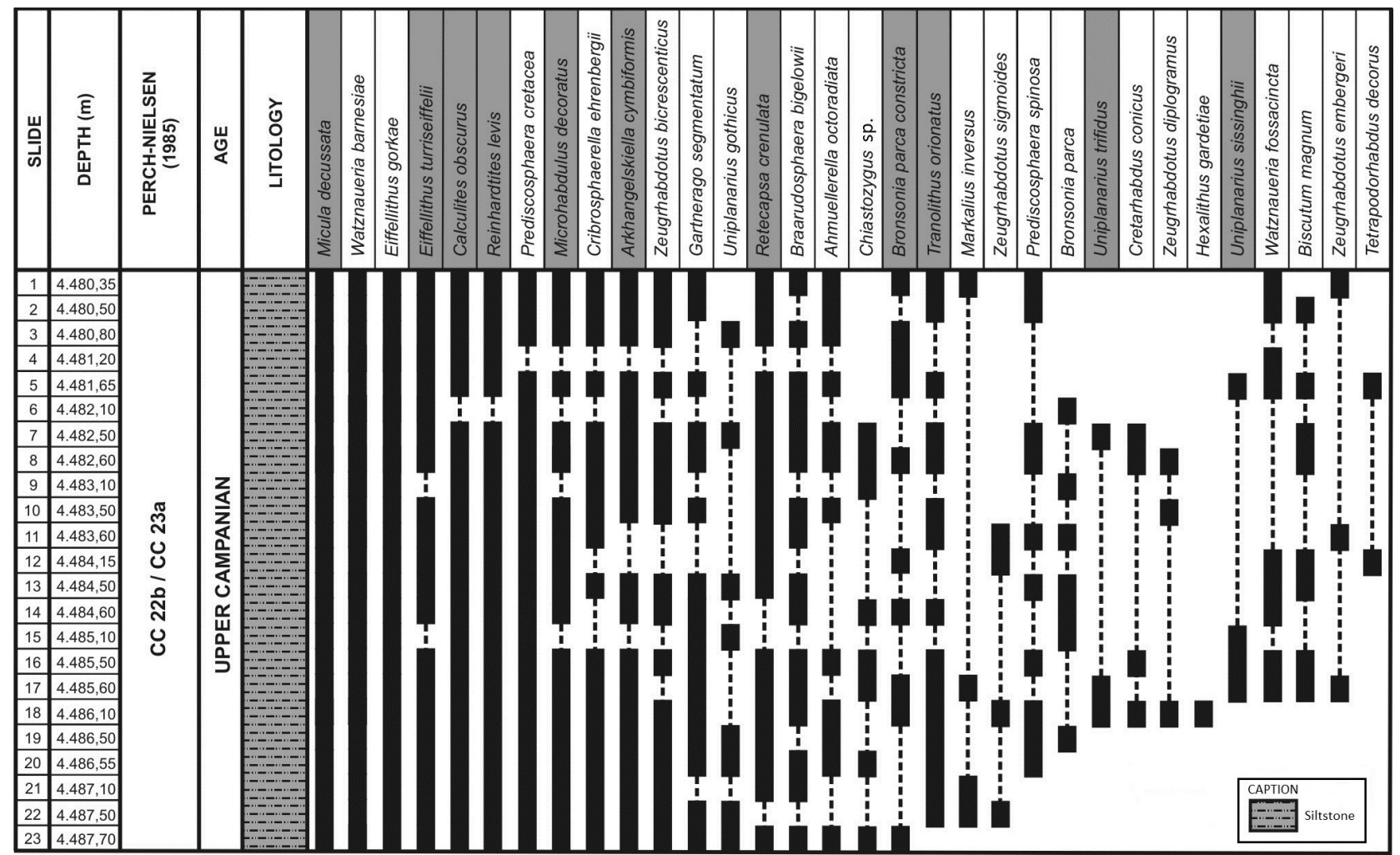

Figure 6. Distribution of calcareous nannofossil species in well 2-RSS-1. The species marked in gray are the Cretaceous calcareous nannofossil markers proposed by Perch-Nielsen (1985). Dotted lines indicate just inferred occurrence. 


\section{FINAL CONSIDERATIONS}

Taking into account the analyses carried out in the interval between 4,480.35-4,487.70 $\mathrm{m}$ of well 2-RSS-1, drilled in the offshore portion of the Pelotas Basin, thirty-two species of calcareous nannofossils were identified (Appendix 1). Eleven of them are present in the range of the Cretaceous biostratigraphic markers proposed by Sissingh (1977) and Perch-Nielsen (1985): A. cymbiformis, B. parca constricta, $C$. obscurus, E. turriseiffelii, $M$. decoratus, $M$. decussata, $R$. levis, $R$. crenulata, $T$. orionatus, $U$. sissinghii and $U$. trifidus. Broinsonia parca constricta and $R$. levis are the most important species observed. These species had a short time range and wide geographic distribution. Their occurrences throughout the material studied indicate that the strata was deposited in the upper Campanian boundary.

\section{ACKNOWLEDGMENTS}

The authors are grateful to J.C. Coimbra for allowing the use of the samples for this study, as well as R.L. Antunes, F.H.O. Lima and A. Concheyro for discussions, and the staff of the Laboratório de Micropaleontologia (UNISINOS) for all the support.

\section{REFERENCES}

Anjos, G.S. 2004. Bioestratigrafia (Foraminiferida) do MiocenoPlioceno da Plataforma de Florianópolis, porção setentrional da Bacia de Pelotas. Programa de Pós-graduação em Geociências, Universidade Federal do Rio Grande do Sul, M.Sc. thesis, 80 p.

Anjos, G.S. \& Carreño, A.L. 2004. Bioestratigrafia (Foraminiferida) da sondagem 1-SCS-3B, Plataforma de Florianópolis, Bacia de Pelotas, Brasil. Revista Brasileira de Paleontologia, 7(2):127138.

Antunes, R.L. 1997. Introdução ao estudo dos nanofósseis calcários. Rio de Janeiro, Instituto de Geociências da UFRJ, 115 p.

Arai, M.; Masure, E. \& Lemos, V.B. 2006. Occurrence of a highdiversity Aptian microphytoplanktonic assemblage in Pelotas Basin (Southern Brazil): its implication for the Early Cretaceous history of the South Atlantic. In: SIMPÓSIO DO CRETÁCEO DO BRASIL, 7/SIMPÓSIO DO TERCIÁRIO DO BRASIL, 1, 2006. Boletim de Resumos, São Pedro, UNESP, p. 12.

Azevedo, R.L.M. 2004. Paleoceanografia e a evolução do Atlântico Sul no Albiano. Boletim de Geociências da Petrobras, 12(2):231249.

Bown, P.R. \& Young, J.R. 1997. Mesozoic calcareous nannoplankton classification. Journal of Nannoplankton Research, 19:21-36.

Bueno, G.V.; Zacharias, A.A.; Oreiro, S.G.; Cupertino, J.A.; Falkenhein, F.U.H. \& Martins Neto, M.A. 2007. Bacia de Pelotas. Boletim de Geociências da Petrobras, 15(2):551-559.

Burnett, J.A. 1998. Upper Cretaceous. In: P.R. Bown (ed.) Calcareous Nannofossil Biostratigraphy, Chapman-Hall, p. 132199.

Carreño, A.L.; Coimbra, J.C. \& Carmo, D.A. 1997. Biostratigraphy of the Late Neogene and Quaternary ostracods in the Pelotas Basin, Southern Brazil. Gaia, 14:33-43.

Ceolin, D. \& Fauth, G. 2009. Upper Cretaceous Ostracoda from the Pelotas Basin, Southern Brazilian continental margin. In: INTERNATIONAL SYMPOSIUM ON OSTRACODA, 16, 2009. Abstracts, Brasília, IRGO/UnB, p. 74.

Closs, D. 1970. Estratigrafia da Bacia de Pelotas, Rio Grande do Sul. Iheringia, Série Geologia, 3:3-37.

Coimbra, J.C.; Carreño, A.L. \& Anjos-Zerfass, G.S. 2009. Biostratigraphy and paleoceanographical significance of the Neogene planktonic foraminifera from the Pelotas Basin, southernmost Brazil. Revue de Micropaléontologie, 52:1-14.

Dias, J.L.; Sad, A.R.E.; Fontana, R.L. \& Feijó, F. 1994. Bacia de Pelotas. Boletim de Geociências da Petrobras, Rio de Janeiro, 8(1):235-245.

Fontana, R.L. 1996. Geotectônica e sismoestratigrafia da bacia de Pelotas e plataforma de Florianópolis. Programa de Pós-graduação em Geociências, Universidade Federal do Rio Grande do Sul, Ph.D. thesis, 214 p.

Gomide, J. 1989. Bacia de Pelotas - biocronoestratigrafia baseada em nanofósseis calcários. In: CONGRESSO BRASILEIRO DE PALEONTOLOGIA, 11, 1989. Anais, Curitiba, SBP, p. 338351.

Gonçalves, A.; Oliveira, M.A.M. \& Motta, S.O. 1979. Geologia da bacia de Pelotas e da plataforma de Florianópolis. Boletim Técnico da Petrobrás, 22(3):155-226.

Koutsoukos, E.A.M. 1982. Geohistória e paleoecologia das bacias marginais de Florianópolis e Santos. In: CONGRESSO BRASILEIRO DE GEOLOGIA, 32, 1982. Anais, Salvador, SBG, p. 2369-2382.

Madeira-Falcetta, M.; Thiesen, Z.V.; Bertels, A. \& Kotzian, S.B. 1980. Foraminíferos e radiolários de testemunhos da plataforma continental e talude do Rio Grande do Sul, Brasil. In: CONGRESSO BRASILEIRO DE GEOLOGIA, 31, 1980. Anais, Balneário Camboriú, SBG, p. 3020-3100.

Milani, E.J.; França, A.B. \& Schneider, R.L. 1994. Bacia do Paraná. Boletim de Geociências da Petrobras, 8(1):69-82.

Ornellas, L.P. 1981. Os ostracodes e seu significado na interpretação dos eventos cenozóicos na bacia de Pelotas, RS: transgressões, regressões, paleoecologia e bioestratigrafia. Programa de Pós-graduação em Geociências, Universidade Federal do Rio Grande do Sul, Ph.D. thesis, 217 p.

Perch-Nielsen, K. 1985. Mesozoic calcareous nannofossils. In: H.M. Bolli; J.B. Saunders \& K. Perch-Nielsen (eds.) Plankton Stratigraphy, Cambridge University Press, v. 1, p. 329-426.

Premaor, E.; Fischer, T.V.; Arai, M. \& Souza, P.A. 2007. Palinologia da bacia de Pelotas: dados preliminares sobre a seção cretácica. In: CONGRESSO BRASILEIRO DE PALEONTOLOGIA, 20, 2007. Anais, Búzios, SBP, p. 231.

Regali, M.S.P.; Uesugui, N. \& Santos, A.S. 1974. Palinologia dos sedimentos meso-cenozóicos do Brasil (I). Boletim Técnico da Petrobrás, 17(3):177-191.

Roth, P.H. 1978. Cretaceous nannoplankton biostratigraphy and oceanography of the northwestern Atlantic Ocean. Initial Reports of the DSDP, 44:731-760.

Sanguinetti, Y.T. 1980. Bioestratigrafia (ostracodes) do Mioceno da bacia de Pelotas, Rio Grande do Sul. Pesquisas, 13:7-34.

Sissingh, W. 1977. Biostratigraphy of Cretaceous calcareous nannoplankton. Geologie en Mijnbouw, 56(1):37-65.

Thiesen, Z.V. 1977. Bolivinitidae e Caucasinidae (Foraminiferida) do Cenozóico superior da bacia de Pelotas, Rio Grande do Sul. Acta Geológica Leopoldesina, 2(3):8-32.

Received in March, 2010; accepted in October, 2010. 
Appendix 1. List of taxa identified in this study.

\section{Heterococcoliths}

Order Eiffellithales Rood, Hay \& Barnard, 1971

Family Chiastozygaceae Rood, Hay \& Barnard, 1973 emend. Varol \& Girgis, 1994

Genus Ahmuellerella Reinhardt, 1964 Ahmuellerella octoradiata (Górka, 1957) Reinhardt, 1966 (Figure 3A)

Genus Tranolithus Stover, 1966

Tranolithus orionatus (Reinhardt, 1966) Reinhardt, 1966 (Figure 3B)

Genus Reinhardtites Perch-Nielsen, 1968

Reinhardtites levis Prins \& Sissingh in Sissingh, 1977 (Figure 3C)

Genus Zeugrhabdotus Reinhardt, 1965

Zeugrhabdotus bicrescenticus (Stover, 1966) Burnett in Gale et al., 1996 (Figure 3D)

Zeugrhabdotus diplogramus (Deflandre in Deflandre \& Fert, 1954) Burnett in Gale et al., 1996 (Figure 3E)

Zeugrhabdotus embergeri (Noël, 1958) Perch-Nielsen, 1984 (Figure 3F)

Zeugrhabdotus sigmoides (Bramlette \& Sullivan, 1961) Bown \& Young, 1997 (Figure 3G)

Genus Chiastozygus Gartner, 1968

Chiastozygus sp. (Figure 3H)

Family Eiffellithaceae Reinhardt, 1965

Genus Eiffellithus Reinhardt, 1965

Eiffellithus gorkae Reinhardt, 1965 (Figure 3I)

Eiffellithus turriseiffelii (Deflandre in Deflandre \& Fert, 1954) Reinhardt, 1965 (Figure 3J)

Order Podorhabdales Rood, Hay \& Barnard, 1971 emend. Bown, 1987

Family Axopodorhabdaceae Bown \& Young, 1997

Genus Cribrosphaerella Deflandre in Piveteau, 1952

Cribrosphaerella ehrenbergii (Arkhangelsky, 1912) Deflandre in Piveteau, 1952 (Figure 3K)

Genus Tetrapodorhabdus Black, 1971

Tetrapodorhabdus decorus (Deflandre in Deflandre \& Fert, 1954) Wind \& Wise in Wise \&Wind, 1977 (Figure 3L)

Family Biscutaceae Black, 1971

Genus Biscutum Black in Black \& Barnes, 1959

Biscutum magnum Wind \& Wise in Wise \& Wind, 1977 (Figure 3M)

Family Prediscosphaeraceae Rood, Hay \& Barnard, 1971

Genus Prediscosphaera Vekshina, 1959

Prediscosphaera cretacea (Arkhangelsky, 1912) Gartner, 1968 (Figure 3N)

Prediscosphaera spinosa (Bramlette \& Martini, 1964) Gartner, 1968 (Figure 30)

Family Cretarhabdaceae Thierstein, 1973

Genus Cretarhabdus Bramlette \& Martini, 1964

Cretarhabdus conicus Bramlette \& Martini, 1964 (Figure 3P)

Genus Retecapsa Black, 1971

Retecapsa crenulata (Bramlette \& Martini, 1964) Grün in Grün \& Allemann, 1975 (Figure 3Q)

Order Watznaueriales Bown, 1987

Family Watznaueriaceae Rood, Hay \& Barnard, 1971

Genus Watznaueria Reinhardt, 1964

Watznaueria barnesiae (Black, 1959) Perch-Nielsen, 1968 (Figure 3R)

Watznaueria fossacincta (Black, 1971) Bown in Bown \& Cooper, 1989 (Figure 3S)

Order Arkhangelskiales Bown \& Hapton in Bown \& Young, 1997

Family Arkhangelskiellaceae Bukry, 1969 emend. Bown \& Haptom in Bown \& Young, 1997

Genus Arkhangelskiella Vekshina, 1959

Arkhangelskiella cymbiformis Vekshina, 1959 (Figure 3T)

Genus Broinsonia Bukry, 1969

Broinsonia parca (Stradner, 1963) Bukry, 1969 (Figure 4A)

Broinsonia parca constricta (Hattner et al., 1980) Perch-Nielsen, 1984 (Figure 4B)

Family Kamptneriaceae Bown \& Hapton in Bown \& Young, 1997

Genus Gartnerago Bukry, 1969

Gartnerago segmentatum (Stover, 1966) Thierstein, 1974 (Figure 4C)

Heterococcoliths of uncertain affinities

Genus Markalius Bramlette \& Martini, 1964

Markalius inversus (Deflandre in Deflandre \& Fert, 1954) Bramlette \& Martini, 1964 (Figure 4D)

\section{Holococcoliths}

Family Calyptrosphaeraceae Boudreaux \& Hay, 1969

Genus Calculites Prins \& Sissingh in Sissingh, 1977

Calculites obscurus (Deflandre, 1959) Prins \& Sissingh in Sissingh, 1977 (Figure 4E)

\section{Nannoliths}

Family Braarudosphaeraceae Deflandre, 1947

Genus Braarudosphaera Deflandre, 1947

Braarudosphaera bigelowii (Gran \& Braarud, 1935) Deflandre, 1947 (Figure 4F) 
Family Microrhabdulaceae Deflandre, 1963

Genus Microrhabdulus Deflandre, 1959

Microrhabdulus decoratus Deflandre, 1959 (Figure 4G)

Family Polycyclolithaceae Forchheimer, 1972 emend. Varol, 1992

Genus Uniplanarius Hattner \& Wise, 1980

Uniplanarius gothicus (Deflandre, 1959) Hattner \& Wise, 1980 (Figure 4H)

Uniplanarius sissinghii Perch-Nielsen, 1986b (Figure 4I)

Uniplanarius trifidus (Stradner in Stradner \& Papp, 1961) Hattner \& Wise, 1980 (Figure 4J)

Genus Micula Vekshina, 1959

Micula decussata Vekshina, 1959 (Figure 4K)

Genus Hexalithus Gardet, 1955

Hexalithus gardetiae Bukry, 1969 (Figure 4L) 